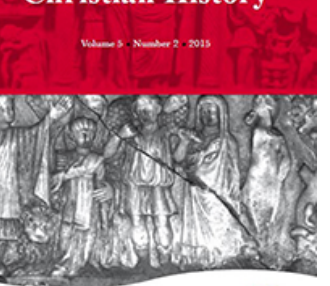

\title{
Why Pray? Augustine of Hippo's Multifaceted Doctrine of Prayer
}

\section{Matthew W. Knotts \& Anthony Dupont}

To cite this article: Matthew W. Knotts \& Anthony Dupont (2015) Why Pray? Augustine of Hippo's Multifaceted Doctrine of Prayer, Journal of Early Christian History, 5:2, 49-75, DOI: 10.1080/2222582X.2015.11877326

To link to this article: https://doi.org/10.1080/2222582X.2015.11877326

\section{Published online: 24 May 2017.}

Submit your article to this journal $\sqsubset$

山 Article views: 59

Q View related articles ๘

View Crossmark data $\nearrow$ 


\title{
WHY PRAY? AUGUSTINE OF HIPPO'S MULTIFACETED DOCTRINE OF PRAYER
}

\author{
Matthew W. Knotts
}

Katholieke Universiteit Leuven and Research Foundation-Flanders

\section{Anthony Dupont}

Katholieke Universiteit Leuven

\section{ABSTRACT}

Augustine's understanding of knowledge is grounded in Christ, the eternal wisdom incarnate. Because Christ is the source and summit of knowledge, one's approach to the fullness of truth must pass through prayer, not least of all its highest form, the divine liturgy. With this point established, we proceed to consider Augustine's exegesis of certain key scriptural passages, in particular Matthew 6 and John 17. In the former, Augustine draws from the Pater Noster in order to show how he understands the importance of living according to the true meaning of one's prayers, and this with respect to certain key controversies he faced during his episcopate. We conclude by looking at his discussion of Christ's High-Priestly Prayer (John 17), suggesting that Augustine sees here a unique self-disclosure of the inner life of the Trinity, which provides the template for transforming oneself in such a way that one does not simply pray but even becomes prayer.

Keywords: Augustine; sapientia; mystagogy; liturgy; prayer; patristic exegesis

\section{UNISA}




\section{INTRODUCTION}

This paper is motivated by two related concerns. The first relates to prayer in the overall spectrum of Augustine's oeuvre. Augustine himself was a man of prayer. As a bishop and pastor, it is no exaggeration to say that prayer was his job, not to mention his vocation. We also know that prayer played a fundamental role in shaping Augustine's life, as he prayed in an Italian garden just prior to his conversion experience, and recited the Psalms as he lay dying in North Africa decades later. His very life was imbued with prayer, as some of the most important works he composed, such as Soliloquia and Confessiones, constitute prayers to God. ${ }^{1}$ For Augustine, speculative theology and discursive philosophy achieved their true end in the contemplation of the fullness of Truth, in conversation, communication, and communion with God, to wit, in prayer.

Augustine held that raising one's heart and one's mind to God would imbue one with a sense of humility and simplicity, thus reorienting one's ontological perspective. Through prayer one could also engage, writes Dominique Doucet, in his analysis of Augustine's philosophical Christology, in a search, both for the foundation of one's own existence and that of all reality. ${ }^{2}$ But above all, prayer and correct worship result in one's transfiguration, and indeed, deification. This is accomplished through recta religio, prayer, true worship, which for Augustine is only possible through Christ, ${ }^{3}$ whom Augustine believed to teach one, by both word and deed, how to pray in spirit and in truth. Therefore we have deemed it particularly interesting to focus on Augustine's exegesis of biblical passages in which Christ himself is depicted as praying, which implies a form of mystagogy and pedagogy: he teaches one that prayer is necessary in order to attain wisdom, and he shows one how to do it, accompanying one along one's path into true worship. Prayer enjoyed a preeminent place not simply in Augustine's personal piety, but in his theological and philosophical doctrine as well, a point, which, we argue, has not been sufficiently treated.

Secondly, Augustine's understanding of sapientia, which, as we shall see, is integrally connected with his understanding of prayer, has also received relatively little attention in the last several decades, with two notable exceptions by Ragnar Holte $^{4}$ and Goulven Madec, ${ }^{5}$ respectively. However, sapientia as such is seldom

1 E.g. J. Doignon, 'La prière liminaire des Soliloquia, dans la ligne philosophique des dialogues des Cassiciacum,' in Augustiniana Traiectina. Communications au Colloque International d'Utrecht 1986 (ed. J. den Boeft and J. van Oort; Paris: Études Augustiniennes, 1987), 85-105.

2 D. Doucet, 'Recherche de Dieu, Incarnation et philosophie: Sol. I, 1, 2-6,' Revue des Études Augustiniennes et Patristiques 36 (1990): 91.

3 See D. V. Meconi, 'Becoming Gods by Becoming God's: Augustine's Mystagogy of Identification,' Augustinian Studies 39.1 (2008): 61-74.

4 R. Holte, Béatitude et sagesse: St Augustin et le problème de la fin de l'homme (Paris: Études Augustiniennes, 1962).

5 G. Madec, 'Christus, scientia et sapientia nostra: Le principe de cohérence de la doctrine augustinienne,' Recherches Augustiniennes 10 (1976): 77-85. 
discussed in the literature, and even Michel René Barnes has stated that the reading of Augustine on sapientia needs to be 're-worked'. ${ }^{6}$ Whilst we realise that such a task can hardly be accomplished in a single essay, we hope in what follows to contribute something to the successful completion of this task.

This essay will consist of three moments through which we shall progressively reveal the inner logic at work in Augustine's understanding of prayer and how it is integrally connected with other aspects of his theological doctrine in general, and sapientia in particular, thus revealing the intrinsically mystagogical nature of prayer in Augustine's mind-set. First, we shall explain how Augustine's goal of arriving at sapientia became a matter of seeking Christ, the incarnate Sapientia Dei. But Christ is most fully encountered in and through prayer, above all the prayer of his body, the church, in her Scriptures, her sacraments, and above all, her divine liturgy, through which one is initiated into and progressively grows in one's knowledge of the divine mysteries. Hence in order to attain to wisdom, one had to engage in true worship, the point which will constitute our second focus. Finally, we shall consider two case studies of a sort, that is, Augustine's exegesis of two biblical passages in which Christ himself is depicted praying. The first is Matthew 6:12, in which Christ teaches his followers the Pater Noster, and the second John 17, the so-called High-Priestly Prayer, in which Christ is seen in a candid moment of profound communication with his Father. Paul van Geest understands a mystagogue as one who attempts 'to kindle a desire in people for the incomprehensible and unspeakable mystery behind everything and everyone', ${ }^{7}$ and our contention in this essay will be that this reading of Augustine is confirmed when one examines Augustine's theology through the lens of prayer and sapientia.

\section{SAPIENTIA DEI EST CHRISTUS: 'A ROSE BY ANY OTHER NAME WOULD SMELL AS SWEET'}

Our first task is to sketch the course of the path that began with the classical understanding of philosophy in its etymological sense and terminated at the incarnate Christ, with whom Augustine identified sapientia. From an early stage of his Christian period after his Milanese conversion of 386 C. E., Augustine acknowledged sapientia as the goal of both the philosopher and the Christian, indeed, of the Christian philosopher. As an heir both to the tradition of classical antiquity and early Christianity, inter alia, Augustine inherited and transformed the concept of sapientia. The goal of classical philosophy was to arrive at the highest beatific wisdom, which Augustine understood as requiring a particular way of living,

\footnotetext{
6 Private conversation in the context of the North American Patristics Conference, May 2014, Chicago.

7 P. van Geest, The Incomprehensibility of God: Augustine as a Negative Theologian (Late Antique History and Religion 4; Leuven: Peeters, 2011), 65.
} 
transcending the merely 'intellectual' and abstract 'rational,' and hence including aspects of the ethical and spiritual life. ${ }^{8}$ So from his earliest days as a 'philosophical' Christian, we can see that Augustine linked philosophy with prayer. Thus we can understand Augustine's thinking as arising out of the classical context which he inhabited, yet increasingly influenced by his Christian sympathies.

In his Soliloquia (386-387), a relatively early work written immediately after his conversion as an attempt rationally to grasp his conversion, Augustine describes sapientia as the contemplation of the highest good, a definition which evokes those of Plato and Aristotle, respectively. ${ }^{9}$ In his earliest extant work, Contra academicos (386), Augustine states, following the antique tradition, that sapientia constitutes the ultimate goal of philosophy, yet a goal which is nevertheless unattainable on this side of the veil. In the same text Augustine claims that even though the end of the search for wisdom is eschatological in nature, one can grow in wisdom in this life, as well as become pure in the search for it, which will prepare one for full beatitude after death. Hence his theory of sapientia from his earliest Christian days admits not only of an ethical, but also of a strongly mystical and eschatological character. ${ }^{10}$

Augustine's De uera religione, completed in 390, represents a definitive statement of his early thinking. The topic of the work is correct worship, religio, which Augustine concludes is essentially Trinitarian in nature. ${ }^{11}$ Moreover, he identifies true religion (that is, true worship) with true philosophy. Augustine saw Christianity as the only true philosophy because of its universality and its possession of Christ's revelation in Scripture. ${ }^{12}$

After the completion of De uera religione, Augustine began his study of Paul in 392, from which point onwards his doctrine of sapientia took a more profoundly christological turn, resulting in a shift to a more biblically informed notion of sapientia, so much so that later, Augustine could write, sapientia pietatis est fructus, 'Wisdom is the fruit of piety. ${ }^{13}$ Indeed, Augustine states that there is no wisdom without pietas, qua recte colitur unus Deus, 'Piety, by which the one God is correctly worshipped. ${ }^{14}$ Wisdom for Augustine requires correct understanding, which in turn requires correct worship, recta religio. This position becomes clear shortly thereafter in works from a liminal time in his life and career, notably his De doctrina christiana

8 G. van Riel, 'La sagesse chez Augustin: De la philosophie à l'Écriture,' in Augustin philosophe et prédicateur: Hommage a Goulven Madec (Collection des Études Augustiniennes, Série Antiquité 195; ed. I. Bochet; Paris: Institut d’Études Augustiniennes, 2012), 391.

9 Ibid., 390.

10 Ibid.

11 J. Lössl, 'The One (unum) - A Guiding Concept in De uera religione: An Outline of the Text and the History of Its Interpretation,' Revue des Études Augustiniennes 40 (1994): 79, 87.

12 T. Finan, 'St Augustine on the „mira profunditas” of Scripture: Texts and Contexts,' in Scriptural Interpretation in the Fathers: Letter and Spirit (ed. T. Finan and V. Twomey; Dublin: Four Courts, 1995), 188.

13 Van Riel, 'La sagesse chez Augustin,' 396.

14 G. Madec, 'Une lecture de Confessions VII,' Recherches Augustiniennes 10 (1975): 101. 
(books 1-3 [396], books 3b-4 [426/427]) and his Confessiones (397/401), the latter of which contains no fewer than sixty instances of the term sapientia, sixteen of which are taken from Scripture. ${ }^{15}$ Even later in De Trinitate 14.12.15 (411-427), Augustine quotes Job 28:28, which states that true wisdom consists in the proper worship of God. ${ }^{16}$ Yet more remarkable still is that in the Confessiones, one begins to see the theme which will only become more pronounced throughout Augustine's mature theological career, namely the idea of Christ as Wisdom itself, the Wisdom of God.

As Augustine writes in his Confessiones 5.3.5, ipse autem unigenitus factus est nobis sapientia et iustitia, 'The only-begotten himself has become for us wisdom and justice.' Here and elsewhere Augustine identifies Christ with Wisdom itself, the Wisdom of God. ${ }^{17}$ Because of this coincidence of Christ and sapientia, Augustine came to hold, like other church fathers before him, that Christ completes the classical programme of philosophy, for Christ is the very same wisdom of which Cicero spoke in his Hortensius, and of which the Platonists and others were vouchsafed certain opaque disclosures. ${ }^{18}$ Moreover, as the Wisdom of God incarnate, Christ came for the purpose of offering salvation, which underscores the necessarily soteriological and eschatological nature of any relation with Christ. ${ }^{19}$ Thus theology and philosophy converge for Augustine, as the quest for wisdom meets the search for Christ, the eternal Wisdom of God. ${ }^{20}$

One does not arrive at the Truth, and therefore Christ, solely through the intellect; ultimately it was in prayer that Augustine most clearly if still imperfectly contemplated Christ as the way and the goal of human life, which is only realised beyond this world. As Trottmann writes, 'if the realisation of the goal of the human soul is wisdom, that is again like theosebia, which is to say, as true worship (uerum cultum) rendered to God which is placed in an eschatological perspective by relation to the beatific vision. ${ }^{21}$ The upshot, as Gerd Van Riel puts it, is a 'Christological

15 P. Burton, 'The Vocabulary of the Liberal Arts in Augustine's Confessions,' in Augustine and the Disciplines (ed. K. Pollmann and M. Vessey; Oxford: Oxford University Press, 2005), 158.

16 C. Trottmann, 'La Trinité de la Sagesse: Contemplation philosophique et guérison mystique,' Questio 6 (2006): 38.

17 Cf. Burton, 'Vocabulary of the Liberal Arts,' 158.

18 I. Bochet, ‘,Non aliam esse philosophiam (...) et aliam religionem“ (Augustin, De uer. rel. 5, 8),' in Les Apologistes chrétiens et la culture grecque (ed. B. Pouderon and J. Doré; Théologie Historique 105; Paris: Beauchesne, 1998), 350.

19 E. F. Kuehn, 'The Johannine Logic of Augustine's Trinity: A Dogmatic Sketch,' Theological Studies 68 (2007): 589.

20 I. Bochet, 'Herméneutique, apologétique et philosophie. Recherches sur Augustin. Exposé de soutenance en vue de l'obtention d'une these d'Habilitation à Diriger des Recherches, Paris IVSorbonne, 11 octobre 2002,' Revue des Études Augustiniennes et Patristiques 48 (2002): 326.

21 Trottmann, 'La Trinité,' 46. The original text reads: 'si l'usage du sommet de l'âme humaine est sagesse, c'est à nouveau comme theosebia, c'est-à-dire comme vrai culte rendu à Dieu (uerum cultum) qu'il va être mis en perspective eschatologique par rapport à la vision béatifique.' 
interpretation of wisdom in an eschatological context. ${ }^{22}$ Elsewhere Augustine makes clear that eternal life requires knowledge of God, which is only possible through Christ. ${ }^{23}$ According to Paul van Geest, one of the fundamental points which Augustine sought to emphasise in his theology is that certain truths, and especially truths about God, escape complete knowledge and understanding on this side of the veil. Hence the search for truth and wisdom transcends the merely intellectual and comes to include the dispositions and attitudes of the hearts of seekers of truth. In this way, according to Van Geest, Augustine is a true mystagogue. ${ }^{24}$

What this implies is that Augustine's discussion of sapientia is ultimately about something more than just a theory about (the conditions of) knowledge, but admits of an eschatological character, indeed, a mystical one, in that it pertains to the soul's intimate union with God, not only in heaven, but already, albeit incompletely, here on earth. ${ }^{25}$

Augustine believes that the 'philosophical' understanding of sapientia is realised and truly embodied in Christ, the incarnate Word. ${ }^{26}$ So whilst Augustine takes the remarkable step of identifying Christ with the goal of philosophy's quest for knowledge, what is even more distinctive is the shift in values implied by Augustine's understanding of sapientia, as well as the idea that the human person can never attain this goal without divine assistance ${ }^{27}$ It is also important to bear in mind that Augustine thinks that one can only enjoy God perfectly in heaven, in eternity, in other words, only after one's death can one attain the fullness of wisdom. As we have seen, it requires grace, and this assistance is obtained only through prayer. Thus we have identified the Augustinian mystagogical subject, namely Christ, the incarnate Wisdom. Now the question becomes how this knowledge is to be inculcated in one.

\section{TRUE WORSHIP: 'MAY THE DIVINE ASSISTANCE REMAIN ALWAYS WITH US'}

Whilst Augustine viewed the philosophical life as a necessary component of the search for wisdom, he did not believe that it could be accomplished on one's own. Rather, he held that divine assistance was required. However, in this respect, Augustine is not unique or novel per se. The Platonic tradition generally and Plotinus especially emphasised in various and sundry ways the importance of moral purification and heteronomous help in attaining the goal of philosophy.

22 Van Riel, 'La sagesse chez Augustin,' 398, emphases added. The original text reads: 'interprétation christologique de la sagesse dans un contexte eschatologique.'

23 Io. eu. tr. 106.3, 111.5.

24 Van Geest, The Incomprehensibility of God, 66.

25 M.-A. Vannier, 'Creatio,' 'conversio,' 'formatio' chez S. Augustin (Paradosis 31; Fribourg: Éditions universitaires, 1991), 160.

26 Madec, 'Christus,' 80.

27 Van Riel, 'La sagesse,' 405. 
Neoplatonism even incorporated elements of mysticism and monasticism; in fact, Augustine's Ostia vision, recorded in the Confessiones, reads like something from Plotinus, and his reading group at Cassiciacum would not have been out of place in Plato's Academy. Rather, what is distinctive of Augustine's view is his belief in the scandalous instantiation of the eternal Wisdom in the very material universe which was created through him. Moreover, this incarnate Wisdom, before re-ascending to the heavens, had left behind instructions on how to follow Hi there. Scholars such as the Belgian Augustinian Tarsicius-Jan van Bavel, and more recently the American Jesuit David V. Meconi have illuminated Augustine's mature Christology, according to which Christ is not merely a sage or a wise man, but a divine physician whose actions on the human soul effect a transfiguration of the entire person. One's relationship with Christ is mediated primarily through the church, which Augustine identifies with the body of Christ, vivified and guided by the Holy Spirit, to which the soul has access through the church's sacramental life. The task for Augustine was for one to place oneself in a situation in which God's grace could become efficacious in one's life, or to put it even more simply, to allow oneself to be changed and reformed by Christ, the God-man. In this section, we shall first consider Augustine's understanding of this need for divine aid, and then subsequently two of the major media through which such changes could be effected, namely Scripture and the divine liturgy.

\subsection{Deus in adiutorium meum intende}

In his recent monograph, Van Geest places an emphasis on the mystagogical character of Augustine's thought, by which he means in particular the bishop's concern with making clear humanity's radical dependence on the Creator, as well as the existential 'formation' required to accept the ontological limits of human nature. ${ }^{28}$ According to Timothy Maschke, the nexus of Augustine's theology of prayer lies in a 'gracious conformation, the humble restructuring or reforming of the Christian's life to the divine will as empowered by the assurance of God's grace. ${ }^{29}$ But the conformation of the human will to the divine does not lie within our human capacities. Since human beings are born in sin, this transformation needs to be submitted to the care of divine grace. This reality is especially expressed in the Lord's Prayer (Matt. 6:9-13). Even more, the prayer of Matthew 6:12, 'and forgive us our debts as we also have forgiven our debtors', itself is a form of grace. In Enarratio in Psalmum 118.19.7

28 Van Geest, The Incomprehensibility of God, 65-66.

29 Th. Maschke, 'St. Augustine's Theology of Prayer: Gracious Conformation,' in Augustine. Presbyter Factus Sum (Collectanea Augustiniana; ed. J.T.E. Lienhard, C. Muller, R.J. Teske; New York: Peter Lang, 1993), 431. 
(after $419 ?^{30}$ ) Augustine describes various forms of grace: baptism, the help of the Holy Spirit, the prayer of Matthew 6:12. All sins are destroyed by baptism; thanks to the Holy Spirit our desires are counter to the flesh; the prayer of Matthew 6:12 is effective. By being reborn, being helped in the conflict, and praying Matthew 6:12, our heart is purified of its defects. ${ }^{31}$ In Sermo 181 (416-417), Augustine states that by confessing $\sin$ in Matthew 6:12, every stain is wiped away. When a believer dies, all their debts - insofar as they are forgivable - are forgiven, because they are also forgiven by the quotidianae preces. ${ }^{32}$ Writing against Julian of Aeclanum (421/422)

30 The secondary literature related to the dating of Augustine's enarrationes is based on the studies of H. Müller, and we indicate the hypotheses she collected in this regard; Müller, H., 'Enarrationes in Psalmos, A. Philologische Aspekte,' in Augustinus-Lexikon II, 5/6 (ed. Mayer, C., Chelius, K. H.; Basel: Schwabe \& Co., 2001, 804-38.

31 En. Ps. 118.19.7: Fit ergo cor immaculatum membrorum et corporis Christi, gratia Dei per ipsum corporis caput, hoc est per Iesum Christum Dominum nostrum, per regenerationis lauacrum, ubi abolita sunt omnia praeterita peccata nostra, per Spiritus adiutorium, per quod concupiscimus aduersus carnem, ne uincamur in pugna nostra; per dominicae orationis effectum, in qua dicimus: dimitte nobis debita nostra [Matt. 6:12]. Ita donata nobis regeneratione, adiuta conflictione, fusa precatione, fit cor nostrum immaculatum, ut non confundamur; quia et hoc ad iustificationes Dei pertinet, quando inter eius alia praecepta praecipitur: dimittite, et dimittetur uobis; date, et dabitur uobis [Luk. 6:37ff.] [CCL 40 p. 1729/16-26].

Cf. En. Ps. 143.7. The link with Luke 6:37-38 is also established here. Forgiving others has become a condition for being forgiven. All sins are wiped away when we pray Matthew 6:12 with an upright heart and with trust.

32 Serm. 181.7: Et cum de corpore exierit unusquisque, dimittuntur ei omnia, quae talia habebat ut dimitterentur debita; quia et quotidianis precibus dimittuntur [...]. [PL 38 c. 982/52]. Augustine quotes 1 John 1:8 against the Pelagians as argument that one cannot live without sin. Praying the Pater Noster in the Eucharist also illustrates this. The entire church asks for the forgiveness of sins, since it is only the heavenly church that will be spotless (Eph. 5:27). Augustine's sequel in Serm. 181.7 is remarkable. He preaches that human beings can die without sin and be purified. Augustine says that all who leave the body can be forgiven all their peccata if they are debita (Matt. 6:12) that can be acquitted. These can be forgiven by daily prayer. At the hour of death, every Christian can be without sin, in spite of never being so in life. Praying the Lord's Prayer thus guarantees the forgiveness of small sins. This position in Serm. 181.7 is parallel to De natura et gratia 35, 41. Here Augustine replies to Pelagius's question in De natura as to how the iusti depart this life, in sin or without it: Vbi parum adtendit, cum sit acutissimus, non frustra etiam iustos in oratione dicere: dimitte nobis debita nostra, sicut et nos dimittimus debitoribus nostris [Matt. 6:12], Dominumque Christum, cum eandem orationem docendo explicuisset, ueracissime subdidisse: si enim dimiseritis peccata hominibus, dimittet uobis Pater uester peccata uestra [Matt. 6:14]. Per hoc enim cotidianum spiritale quodammodo incensum, quod ante Deum in altare cordis, quod sursum habere admonemur, infertur, etiamsi non hic uiuatur sine peccato, licet mori sine peccato, dum subinde uenia deletur, quod subinde ignorantia uel infirmitate committitur. [CSEL 60 p. 263/4-14]; 'Here, though he is very clever, he does not sufficiently note that even the righteous pray, Forgive us our debts, as we also forgive our debtors (Matt. 6:12), and that, when Christ the Lord taught and explained this prayer, he added, For if you forgive others their sins, your Father will forgive your sins (Matt. 6:14). We offer this daily prayer like spiritual incense before God on the altar of our heart, which we are taught to lift up to the Lord. By means of it we are able to die without sin, even if we cannot live this life without sin, since 
in Contra Iulianum, Augustine explains that the prayer for forgiveness of Matthew 6:12 has a place in the threefold process of justification: 'Furthermore, justification is bestowed upon us in this life according to these three ways: first by the bath of regeneration, through which all sins are forgiven; subsequently, by our struggle with vices, the guilt of which we are absolved; thirdly, when our prayer in which we say, Forgive us our debts (Matt. 6:12) is heard, since - however strongly we fight against vices - we are human beings. God, however, helps us with grace when we fight this corrupted body, He does not forsake us because he hears the ones who come to seek forgiveness. ${ }^{33}$ Augustine clearly considered prayer to be a grace, as a gift of God. For instance, Augustine chides the so-called 'Pelagians' for being too unilateral in considering prayer a merely human initiative. However, Augustine did not often thematise the gratia orationis. The pastor Augustine preferred to stress the human duty to pray because of - as the content of the prayer of Matthew 6:12, in fact, reveals - the human need to receive divine grace.

Augustine's understanding of prayer in relation to sapientia entails a nuanced conception of human knowledge, which suggests an epistemic disparity between knowledge of a particular matter, scientia, and contemplation, sapientia. The latter requires divine assistance and represents the very goal of all knowledge and thought. ${ }^{34}$ Augustine therefore encourages his flock to seek a contemplative vision of God now in this life, even though it will not be perfected until after one's earthly sojourn. ${ }^{35}$ For this, divine aid is required, which enables one to know God and live with him forever, which comes as a result of prayer and recta religio, resulting in

pardon immediately wipes away the sins we repeatedly commit out of ignorance or weakness.' English translation from: J.E. Rotelle (ed.), R. Teske (trans., notes), Answer to the Pelagians, I/23 (The Works of Saint Augustine: A Translation for the 21st Century, I/23; Hyde Park, NY: New City, 1997), 245. É. Rebillard concludes: 'Qu'Augustin croit utile de répéter dans un sermon ce qu'il répondait à une objection de Pélage, sans même faire d'allusion polémique à ce dernier, indique bien que la question peut émouvoir un chrétien. Mourir en état de péché semblerait être la conséquence logique du " nul ne peut vivre sans péché » si souvent répété. Mais, grâce à une pénitence quotidienne, le chrétien, bien qu'il ne puisse pas vivre sans péché, peut ne pas mourir en état de péché.' É. Rebillard, In hora mortis: Évolution de la pastorale chrétienne de la mort aux IVe et Ve siècles (Bibliothèque des Écoles Françaises d'Athènes et de Rome 283; Rome: École Française de Rome, 1994), 166.

33 Contr. Iul. 3.23: Iustificatio porro in hac uita nobis secundum tria ista confertur: prius, lauacro regenerationis, quo remittuntur cuncta peccata: deinde, congressione cum uitiis, a quorum reatu absoluti sumus: tertio, dum nostra exauditur oratio, qua dicimus, dimitte nobis debita nostra [Matt. 6:12]; quoniam quamlibet fortiter contra uitia dimicemus, homines sumus; Dei autem gratia sic nos in hoc corruptibili corpore adiuuat dimicantes; ut non desit propter quod exaudiat ueniam postulantes. [PL $44 \mathrm{c}$. 689/23-32]. Matthew 6:12a erases smaller sins but not crimina (Contr. d. ep. pelag. 1.27; Contr. Iul. 1.27, 2.23). Translations ours.

34 Karla Pollmann, 'Augustine's Hermeneutics as a Universal Discipline!?' in Augustine and the Disciplines (ed. K. Pollmann and M. Vessey; Oxford: Oxford University Press, 2005), 229-30.

35 E. Cassidy, 'Augustine's Exegesis of the First Epistle of John,' in Scriptural Interpretation in the Fathers: Letter and Spirit (ed. T. Finan and V. Twomey; Dublin: Four Courts, 1995), 217. 
one's spiritual purification. ${ }^{36}$ One is hindered in one's faith by weakness and sin, but through piety one has the opportunity to believe. ${ }^{37}$ Thus Trottmann: 'It is necessary for the summit of the spiritual soul, in returning to its creative source, to rediscover its original form of the image of God which has been deformed by sin. In rendering him such worship, in spirit and in truth, [the soul] is deified, but in order to be more perfectly itself in the sight of God. ${ }^{38}$ One's very being is transfigured, purified, healed, and indeed, re-created in the divine light of the Creator. ${ }^{39}$ The means by which this process is consummated are constituted by and mediated through: (1) Scripture and (2) the church, which in a certain sense Augustine identifies with Christ, sapientia itself.

\subsection{In sermonibus tuis}

Augustine views Scripture as a pre-eminent repository of supernal wisdom. However, though Augustine openly praises the benefits of reading Scripture, he nonetheless warns that God's help is necessary in order to obtain the grace and illumination required to read it correctly. ${ }^{40}$ In order to understand and penetrate the deeper layers of truth, one must first approach the text in faith; access to the sapiential knowledge latent in Scripture requires a 'confession' on the part of the reader. ${ }^{41}$ In this regard, Augustine sharply contrasts worldly wisdom and the wisdom of heaven, true wisdom, the latter of which implies a recognition of God as the foundation of all reality, a realisation which in turn leads one to give thanks to God 'en esprit et en vérite.' ${ }^{42}$ The upshot is that Augustine envisages not just the study of Scripture, but even human life itself, as a process during which one is gradually purified and led to knowledge of Christ through dialogue and prayer. ${ }^{43}$

Augustine believes that in his own life he was led along this path by God. Yet this teaching is not a simple conferral of information, but rather implies an affective sense in which one's very being is transformed by the love it bears for its Lord. As Isabelle Bochet explains this point, "this interior teaching is a relation where the

\footnotetext{
36 Van Riel, 'La sagesse,' 391.

37 Io. eu. tr. 111.1.

38 Trottmann, 'La Trinité,' 38-39: 'Il s'agit pour le sommet de l'âme spirituelle, en remontant vers sa source créatrice, de retrouver sa forme originelle d'image de Dieu déformée par le péché. En lui rendant un tel culte, en esprit et en vérité, elle est déifiée, mais pour être plus parfaitement ellemême sous le regard de Dieu.'

39 Ibid., 39.

40 I. Bochet, 'Interprétation scripturaire et compréhension de soi: Du De Doctrina Christiana aux Confessions de Saint Augustin,' in Comprendre et interpréter: Le paradigme herméneutique de la raison (ed. J. Greisch; Paris: Beauchesne, 1993), 30; F. Arsenault, Augustin: Qui est Jésus Christ? (Paris: Desclée, 1974), 31.

41 Bochet, 'Interprétation scriptuaire,' 43.

42 Trottmann, 'La Trinité,' 38.

43 Arsenault, Augustin, 44.
} 
subject awaits from the divine Other an ever greater progress in the understanding of truth'.$^{44}$ For Augustine, knowledge is about more than mere intellectual apprehension or the acceptance or the endorsement of certain propositions, but is about the internalisation of a certain content, such that one becomes likened unto that which one knows, for the reason that in fixating one's intellectual gaze upon it, one loves what one knows and seeks to know what one loves. ${ }^{45}$ This transformative aspect of Christ's interaction with the soul is yet more profound, a point which Bochet captures when she writes, 'Through Scripture, the subject is therefore taught, but he is also healed: Christ is the teacher (magister), but he is also the physician (medicus) ${ }^{4}{ }^{46}$ It is not simply or even primarily one's own actions which are efficacious in one's prayer, but rather the fact that the prayerful reading, and indeed, contemplation of Scripture places one in a state in which one can gain access to the benefits and the merits of Christ's passion, by means of which he can heal the soul, imbue it with divine wisdom, and conduct it to eternal life.

Insofar as one bears the imago Dei, one's very act of being is fundamentally responsive to God's initial call, a call which echoes through the Scriptures and which one is enabled to answer fully through Christ's saving actions. ${ }^{47}$ And for Augustine, these acts and their efficacious graces are mediated through the church's liturgical life, in which the correct reading of Scripture is most perfectly realised. ${ }^{48}$

\subsection{Introibo ad altare Dei}

For Augustine, the light of wisdom shines most resplendently in the divine liturgy, for this is the pre-eminent way in which one is incorporated into the church, which just is the body of Christ. ${ }^{49}$ Indeed, Augustine maintains the ultimate inseparability of Christ and the church, ${ }^{50}$ for it is the latter which the former uses as an instrument to lead one into the full contemplation of sapientia in heaven..$^{51}$ According to Robert Wilken, Augustine understands the church as the 'vehicle and context for Christian contemplation'. ${ }^{52}$ In the church, people are enabled to respond to the Father through

44 Bochet, 'Interprétation scriptuaire,' 39: 'cet enseignement intérieur est une relation où le sujet attend de l'Autre divin un progrès toujours plus grand dans l'intelligence de la vérité.'

45 Meconi, 'Becoming Gods,' 69-71.

46 Bochet, 'Interprétation Scriptuaire,' 39: „A travers l'Écriture, le sujet est donc enseigné, mais il est aussi guéri: le Christ est le maitre (magister) mais il est aussi le médecin (medicus)."

47 Cf. M. Drever, 'The Self before God? Rethinking Augustine's Trinitarian Thought,' Harvard Theological Review 100.2 (2007): 241.

48 See Meconi, 'Becoming Gods.'

49 Trottmann, 'La Trinité,' 39.

50 R. Dodaro, "Omnes haeretici negant Christum in carne uenisse“ (Aug., serm. 183.9.13): Augustine on the Incarnation as Criterion for Orthodoxy,' Augustinian Studies 38.1 (2007): 169.

51 En. Ps. 143.1; R. Williams, 'Augustine and the Psalms,' Interpretation 58 (2004): 21.

52 S. Pardue, 'Kenosis and its Discontents: Towards an Augustinian Account of Divine Humility,' Scottish Journal of Theology 65.3 (2012): 284, quoting R. Wilken. 
Christ. ${ }^{53}$ Rowan Williams writes that through his incarnation, Christ 'transfigures [the] human voice,' in particular by incorporating individuals into his body such that they can speak in a unified voice. Whilst the church is essentially social, it also serves as a locus for the individual, supplying one with the necessary resources, conditions, and context for personal growth and, for instance, the correct interpretation of the Scriptures. ${ }^{54}$

This is because in virtue of one's participation in divine worship, one participates in God's Wisdom; by worshiping God, one is most perfectly being formed in sapientia. ${ }^{55}$ As Meconi puts it, the church enables one to become 'divine by worshipping properly'. ${ }^{56}$ One is led to a profound participation in the very life of God, that is, to apotheosis, deification. As Meconi explains, "deification for Augustine is an "ecclesial process" ... only the communion of Christ's people and the liturgical vehicles which causes $[$ sic] this bond, can bring enfleshed human persons to participate in the divine life'. ${ }^{57}$ The true worship of God cleanses and heals the soul and leads to one's 'deification,' the fullness of unity with sapientia. ${ }^{58}$ As Meconi writes, 'The liturgy thus becomes the locus deificandi, the place where the drama of human salvation is not only re-enacted but effected.' ${ }^{59}$

Thus it becomes clear that for Augustine, prayer and liturgical worship prefigure and indeed, participate in the eternal divine liturgy in heaven. The former reflects the latter. Thus in heaven the soul will be involved in the eternal mass; the perfect possession of Wisdom, an ostensibly philosophical or secular pursuit, is ultimately connected with prayer and worship, liturgy and ecclesiology, Christ and his body. ${ }^{60}$ Through the church's liturgical life, and especially the Eucharist, one is brought into direct contact with Christ, the sapientia Dei.

\section{MYSTAGOGY: LEX ORANDI, LEX CREDENDI}

In the foregoing section we have spoken of Augustine's understanding of true worship. On his account, worship can be correct and true, or incorrect and false. The

53 Williams, 'Augustine and the Psalms,' 24.

54 Ibid. Perhaps his ecclesiology is presaged in his early philosophical works such as Sol. and Beata uita, in which Augustine emphasises the importance of community in the search for sapientia and the philosophical life. Not only is one enabled to discern truth in conversation and dialogue, but in the dynamic of the conversation itself, something is generated which exceeds the sum of the capacities of the individuals taking part. So too does the church, incorporated into Christ and vivified by the Holy Spirit, exceed the merits and contributions of each individual believer.

55 Trottmann, 'La Trinité,' 39.

56 Meconi, 'Becoming Gods,' 73.

57 Ibid., 71.

58 Trottmann, 'La Trinité,' 38.

59 Meconi, 'Becoming Gods,' 74.

60 Trottmann, 'La Trinité,' 46. 
fault in the latter lies either with the object which is worshipped, such as an idol, or something in the disposition of the worshipping subject. For our purposes, we shall consider Augustine's discussion of the latter. As we have seen, for Augustine, prayer, Scripture, and especially the divine liturgy provided a mystagogical moment, through which the faithful could enter ever more deeply into the Christian mysteries. Prayer included a fundamentally normative, or better yet, formative aspect. However, Augustine also saw in prayer a crucial descriptive element. Whilst on the one hand, prayer conformed the soul ever more perfectly to its pristine state as an image of God, one's prayers also provided a touchstone of a sort, a guide for separating true Christians from false ones, of separating the good wheat from the chaff. In what follows, we shall focus on this aspect of Augustine's pastoral thought, a very specific application of the general principle of lex orandi, lex credendi.

This theological position was motivated by a pressing practical, pastoral, and even to a certain extent, political concern, namely that of heresy and schism in the late antique church, especially in North Africa. As a prolific Catholic apologist, Augustine's thought was often formulated in response to doctrinal and ecclesiastical crises of his day. One of the great challenges he faced was ad intra, namely how one could differentiate 'true' Christians from 'false' ones. There were many in Augustine's day who could ostensibly endorse his conclusions concerning prayer and the liturgy, and yet disagree on other fundamental matters. Even though some Christians, such as the Donatists and the Pelagians, recited the orthodox formulations of staple Christian prayers, Augustine argued that other words and actions of theirs conflicted with these utterances. Thus the question did not so much centre on prayer itself, but how one ought to pray. Moreover, this is also the principle - within the community of the church - by which to distinguish the good/authentic from the bad/hypocritical Christians who do not live according to the content of their prayers. In other words, it is one thing to hold that prayer is important; it is quite another to pray in the correct way. This was a challenge which Augustine faced at the practical and pastoral level, and which he addressed through his sermons and his discursive theology. One of the questions with which Augustine concerns himself in his exegesis of Matthew 6:12 is an epistemological one, namely: how does one know that one is worshipping correctly and is truly a member of the church in which true worship is possible?

One of the argumentative moves which Augustine made was to demonstrate a basic inconsistency with inauthentic Christians between their words and their deeds. That is, somehow their prayer and worship was inauthentic, as it was vitiated by other beliefs, which could be discerned through their words and actions. One of the key biblical passages which he used to substantiate this argument was Matthew 6, in which Christ, the very Wisdom of God, teaches his followers how to pray, in particular the Oratio Dominica, the Lord's Prayer, to which we now turn our consideration. 


\section{1. 'This Is How You Are To Pray': Augustine on Matthew 6:12}

Reference is made to the prayer of Matthew 6:12 with particular frequency in Augustine's oeuvre: 'Dimitte nobis debita nostra, sicut et nos dimittimus debitoribus nostris;' 'And forgive us our debts as we also have forgiven our debtors. ${ }^{61}$ In Sermo 181 (416-417), Augustine stresses that Christ himself asked us to pray for the forgiveness of sins in this way. This is how the shepherd spoke to his rams, the king to his soldiers, the master to his slaves, Christ to his apostles, the truth to humanity, the most elevated to the humble. ${ }^{62}$ Why does Augustine deem the prayer of Matthew 6:12 as quintessential? We explained above that a part of the answer is that Matthew 6:12 shows 'grace at work', however Augustine does not state this very often. Throughout his collected oeuvre, Augustine's more frequent - almost constant - answer is that the Pater Noster has much to teach us about: a) the Christian life; and b) faith.

\subsubsection{Live according to Your Prayers}

Augustine sees contained in Matthew 6:12 a fundamental norm for Christian life. A constant pastoral-tactical refrain in his use of Matthew 6:12 is: 'forgive to be forgiven.' If we want God to forgive us, we must forgive the sins that have been committed against us. In a proverbial sense, divine forgiveness is the carrot Augustine uses to get the donkey moving - to convince his community to apply forgiveness themselves. He frequently formulates Matthew 6:12 as a juridical petition or court appeal. Sermo 114 (not before 423, probably 424) offers a striking illustration: what is the relationship between asking for forgiveness and forgiving?

61 Augustine's reflections on the Lord's Prayer have been closely studied by P. F. Beatrice and M. O'Connell (trans.), 'Lord's Prayer,' in Augustine through the Ages (ed. A.D. Fitzgerald; Grand Rapids, MI: Eerdmans, 1999), 506-9. R. H. Weaver gives a similar thematic analysis of Augustine's opinion on prayer. The Lord's Prayer is the paradigm of prayer: 'Its petitions establish the direction and parameters of what the believer is to desire and to request (s. 56.3.4).' The prayer's first three petitions ask that we be made acceptable before God. This is a process that begins in the present life but is completed only in eternal life. The last four petitions request what we need for our earthly life. All seven petitions are aimed at one goal only, namely eternal life. Prayer ensures the training of this just desire, i.e. the desire for the eternal and not for the temporal. Ultimately, the desire to conform one's own prayer to God falls short. After all, the praying believer who desires God longs for that which transcends human existence. This is why human beings need the Holy Spirit who transforms human ignorance into a desire for God. Paul's call for incessant prayer (1 Thess. 5:17) expresses the constant desire for God. This praying desire consists of the conformation of one's own life to God. 'Augustine placed particular stress on two such expressions of conformity: forgiveness and almsgiving. The former is an internal act; the latter, an external one (s. 58.9.10). Both are remedies against sin; both are means of achieving peace with one's neighbour; both are tests of integrity in prayer (s. 9.11.17; 56.12.16; 57.12.12).' R.H. Weaver, 'Prayer,' in Augustine through the Ages (ed. A.D. Fitzgerald; Grand Rapids, MI: Eerdmans, 1999), 672-73.

Serm. 181.6 [PL 38 c. 982/26-28]. 
'Quo iure? Quo pacto? Quo placito? Quo cyrografo recitato?' 'By what law? By what contract? By what agreement? By what promise recited in court?' ${ }^{63}$ Matthew 6:12 is the answer to that question. In his sermons, he labels Matthew 6:12 as a pact between humanity and God, ${ }^{64}$ a contract (sponsio) with God, a somewhat 'strange' formulation for a theologian who became known as the doctor gratiae. ${ }^{65}$ The prayer of Matthew 6:12 thus functions as a moral category, an ethical exhortation, a forceful and authoritative - because commissioned by Christ - call to all Christians actively to engage in forgiving. The content of the prayer of Matthew 6:12 thus instructs us about how to live in a Christian way. If we pray it, we have to live accordingly by forgiving our fellow men.

\subsubsection{Believe according to Your Prayers}

For Augustine this petition for forgiveness acquires a greater significance in his polemical exchanges, as he comes to understand the prayer for forgiveness as representing a criterion for orthodoxy. Not understanding - or rather, not wanting to understand - this petition correctly, is an accusation he launches against the Manicheans, the Donatists, and the Pelagians, the fiercest opponents he faced as a bishop and pastor.

In Contra Faustum Manichaeum (397/399), Augustine uses Matthew 6:12 as an argument against Manichean dualism. In his opinion, the Manicheans cannot pray Matthew 6:12 with sincerity on account of their dualism. According to the Manicheans, all sins are caused by the principle of evil, by the gens tenebrarum. As a consequence, a Manichean who prays for the forgiveness of his own sins using Matthew 6:12 should in fact be praying that the gens tenebrarum, which is responsible for all evil in the world, be forgiven. From the perspective of the Manicheans, moreover, God bears the responsibility for the situation of humankind. Augustine replies to this Manichean claim with the question of how God could forgive our debts if he were already in debt to us. In other words, Augustine explains,

63 Serm. 114.5 [RB 73 p. 26/79-80].

Cf. S. Poque, 'Le Christ ,iurisperitus“ et la procédure „per rescriptum“ dans la prédication d'Augustin d'Hippo,' Revue Historique de Droit Français et Étranger 57 (1979): 331-44.

64 Ep. Ioh. Parth. tract. 7.1 (406/407).

65 Serm. 181.8. 'Der letzte Teil der Argumentatio hat stark paränetischen Charakter. Augustin verbindet die Invektive gegen den haereticus fictus nun mit einem Appell an die Gemeinde, die er zu bußfertigem christlichen Leben aufruft, das die schweren Sünden meidet und sich tagtäglich der Vergebung der kleinen versichert. Die Deutung der fünften Vaterunserbitte als sponsio cum Deo mutet vor dem Hintergrund der augustinischen Gnadentheologie befremdlich an; der Bischof ist hier aber offenbar ganz Seelsorger und will den Hörern ein Schema an die Hand geben, das eine unkomplizierte Begründung für die Notwendigkeit gegenseitigen Vergebens bietet: $s i$ dimittis, dimitto, si tenes, teneo. Tu contra te tenes, qui alteri non dimittis.' L. Mechlinsky, Der 'modus proferendi' in Augustins 'sermones ad populum' (Studien zur Geschichte und Kultur des Altertums, Neue Folge, 23; Paderborn: Schöningh, 2004), 253. 
God, who is not mixed with evil, differs from us human beings, who are mixed with evil, to such an extent that he is not indebted to us. Augustine argues that the pact of forgiveness between God and us represented by Matthew 6:12 cannot function within the Manichean dualistic perspective. When Manicheans pray these words, therefore, they do so in a deceptive and blasphemous way. ${ }^{66}$ As such, the prayer of Matthew 6:12 clearly demonstrates the heterodoxy of the primordial Manichean dogma.

In Contra epistulam Parmeniani 2.20 (400), Augustine argues that the Donatists are either: a) being hypocritical, praying Matthew 6:12 while they in fact are convinced that they are not sinful, and thus sin by deceiving others with their feigned humility, or: b) they pray Matthew 6:12 with sincerity, thus admitting they have sins to be forgiven.$^{67}$ However, according to Augustine, the Donatists do not pray Matthew 6:12 with sincerity, because they are convinced they have no sins to be forgiven. And the latter conviction, for Augustine, is not only wrong, as the Donatists also have sinners (schismatics, liars, people who seek their own pleasure) among their ranks, and as even respected Donatists do not deny that they are sinners when they beat their breast as a sign of remorse, it is moreover a serious sin of pride. Augustine elaborates this line of thought further in Ad Cresconium (405/406), linking Matthew 6:12 with 1 John 1:8, 'If we say that we have no sin, we deceive ourselves, and the truth is not in us,' focusing on the basic idea that we are all sinners. ${ }^{68}$ Cresconius claims that sinners should not be allowed to administer baptism. ${ }^{69}$ Augustine responds that

66 Contr. Faust. Mani. 20.17: Nec illud potestis dicere, quod magister ueritatis docuit: dimitte nobis debita nostra, sicut et nos dimittimus debitoribus nostris [Matt. 6:12]. Qui sunt enim debitores uestri, qui in uos peccauerunt? Si gens tenebrarum, numquid ei dimittitis debita, quam usque in finem eradicatam aeterno carcere includitis? Quae autem debita uobis potest ille dimittere, quando ille potius in uos peccauit, cum ad ista uos misit, quam uos in illum, qui mittenti obtemperastis? Aut si propterea ille non peccauit, quia hoc necessitate fecit, maior et uestra necessitas, cum iam in pugna prostrati iaceatis, quam fuit illius, antequam pugnaretis. Iam enim uos patimini commixtum malum, nihil tale ille patiebatur, cum tamen necessitatem, ut uos mitteret, pateretur. Itaque aut ipse potius uobis debet, quod ei dimittatis, aut si nec ipse uobis, multo magis nec uos illi. Vbi sunt ergo sacrificia uestra, simplices ac purae orationes, cum sint fallaces et inpurae blasphemiae? [CSEL 25, 1 pp. 557/27-558/15].

67 Contr. ep. Parm. 2.20: Neque enim non tundunt pectora sua aut cum id faciunt simulate faciunt - quod si ita est, certe uel tunc infeliciter peccant populos suos simulata humilitate fallentes - aut non dicunt in oratione dominica: dimitte nobis debita nostra, sicut et nos dimittimus debitoribus nostris [Matt. 6:12]. [CSEL 51 p. 67/19-24].

68 Cresc. 2.33.

69 Contr. litt. Petil. 2.237 (400/403) counters the argument based on Psalm 140:5: Dixit quoque Dauid: 'oleum peccatoris non unget caput meum,' employed by Petilianus. With Matthew 6:12 Augustine advises, however, that we should be careful not to confuse the traditor with the peccator. The latter category applies to all human beings, including Petilianus. He refers in this regard to Matthew 6:12, the prayer the Lord himself taught to the apostles: Neque enim de illis peccatis hoc petimus, quae nobis in baptismo dimissa sunt. Ergo ista uerba orationis aut non te permittunt esse Dei deprecatorem aut aperiunt peccatorem. [CSEL 51 p. 151/21-23]. 
there is no such thing as a sinless person and that we all pray Matthew 6:12 during the oratio dominica. A person might be correct in claiming that one is not a traditor (surrendering the holy books to the pagan persecutors), or a turificator (offering incense to the pagan gods), or an adulter (adulterer), or a homicida (murderer), or an idolorum cultor (worshipper of idols), or a haereticus, or a schismaticus, but no one can insist that one is not a peccator (sinner). Those who say or think the contrary are filled with the haeretica superbia. No one can say aloud or think in silence that they have no need of the deprecatio of Matthew 6:12. Baptism washes sins away, but after baptism our faults and failings remain. Due to our humana fragilitas, we are never free from fault, no matter how careful we are in obeying the commandments of God. Matthew 6:12 and 1 John 1:8 thus contradict the idea that there are no more sins after the forgiveness of baptism. ${ }^{70}$ Even priests, bishops, all the saints, and the apostles were not sinless, and needed to pray Matthew 6:12, and they willingly did..$^{71}$ In Epistula 185 (417), addressed to Boniface, the tribune responsible for punishing the Donatists, ${ }^{72}$ Augustine argues that if the Donatist church was really without sin, as it wrongly claims, then it would not have to - or be allowed to - pray Matthew $6: 12$, the prayer our Lord himself taught us, and it would be in contradiction of 1 John 1:8. ${ }^{73}$ The prayer of Matthew 6:12 thus clearly refutes one of the central Donatist beliefs.

Jean-Albert Vinel has demonstrated that the daily Lord's Prayer functioned as a liturgical argument against the Pelagians. ${ }^{74}$ In Augustine's anti-Pelagian campaign,

70 Cresc. 2.35 .

71 En. Ps. 36.2.20 (403) contains a refutation of the Donatist belief in the necessity of sinless priests. Augustine insists that priests also have to pray for their own sins, as is evidenced by the fact that the apostles asked their community to pray for them and they themselves prayed Matthew $6: 12 \mathrm{a}$.

72 Ep. 185.38-39.

73 Ep. 185.39. Ep. 185.39-40 argues that previous sins are forgiven in baptism when it is administered in the church. Those who are not baptised cannot pray Matthew 6:12. Based on the hope inspired by 1 John 1:8-9 (the confession of sins leads to God's forgiveness) the entire church prays Matthew 6:12, in order to be purified of every iniquitas and be spotless (Eph. 5:27). Augustine addressed Ep. 189 to the same Boniface - and in the same year, 417 - on the topic of living one's life as a soldier of Christ. Augustine concludes his letter in Ep. 189, 8 by inviting Boniface to thank God for the goodness he already possesses, and to pray for the virtue he lacks together with the forgiveness of the sins that afflict us all. Life on earth, after all, is a perpetual temptation (Job 7:1); Proinde quoniam semper, quam diu es in hoc corpore, necessarium est tibi in oratione dicere, quod Dominus docuit: dimitte nobis debita nostra, sicut et nos dimittimus debitoribus nostris [Matt. 6:12; Luk. 11:4], memento cito ignoscere, si quis in te peccauerit et a te ueniam postulauerit, et ueraciter possis orare et peccatis tuis ueniam ualeas impetrare. [CSEL $57 \mathrm{p}$. 136/18-24]. In Retract. 2.18 (426/427) Augustine 'revises' an anti-Donatist exegesis of Matthew 6:12 to better 'fit' his anti-Pelagian doctrine. He observes in Bapt. that when he uses Ephesians 5:27 against the Donatists this does not mean that the church here on earth is already without macula or ruga. It means rather that the church is being prepared to be without macula or ruga in the future. Indeed, the church prays Matthew 6:12 every day because of the ignorantiae and the infirmitates membrorum suorum.

74 J.-A. Vinel, 'L'argument liturgique opposé par saint Augustin aux Pélagiens,' Questions liturgiques 68 (1987): 209-41. 
this prayer generally illustrates the insufficiency of human capacities. More specifically, it reveals that even after baptism the believer has a need for forgiveness and that the baptised believer cannot resist concupiscentia without the support of grace. Vinel lists the five steps in Augustine's 'argument liturgique': 'In order for the liturgy to show the doctrinal truth it contains, one needs (1) an effective practice or behaviour, (2) covered by the auctoritas Ecclesiae and (3) accomplished in good faith, meaning veraciter et non mendaciter. Given that (4) these movements or words cannot be done or pronounced in vain (non inaniter), it is suitable then to ask oneself about (5) their implicit logic. This refers, in the case of prayer as a request or an act of grace, to the insufficiency of the personal capacities of the praying person. ${ }^{75}$ Matthew 6:12 is a Leitmotiv in Augustine's anti-Pelagian corpus, on the doctrinal level, but also ad hominem: he compares them, for instance, to the Pharisees, who because they deem themselves iusti, are convinced that they do not need to pray Matthew 6:12 to obtain forgiveness. ${ }^{76}$ With pathos, the North African bishops - in Epistula 176.2 despatched to Pope Innocent in 416 - exclaim that the 'Pelagian heretics' rob Christians of the Lord's Prayer by placing the emphasis on the sufficiency of the unaided human free will. According to the African bishops, the Pelagians deny Matthew 6:12 in particular by arguing that once the commandments are known, we are capable in this life of achieving such a degree of righteousness by our free will alone, without the help of the grace of the Redeemer, that we no longer need to pray Matthew 6:12. Similarly, Augustine forcefully preaches that the 'Pelagians' deny what the Lord himself taught about prayer. Even though they do not have the courage to deny it openly, Augustine laments, their arguments imply an annulment of what the Lord taught. After all, if the 'Pelagians' assert that human

75 'Quelle est donc la rationalité qui gouverne ses recours à l'argument liturgique? Du débat avec les pélagiens émergent cinq facteurs. Pour que la liturgie puisse montrer la vérité doctrinale qu'elle recèle, il faut $\left[1^{\circ}\right]$ une pratique ou un comportement effectifs, $\left[2^{\circ}\right]$ couverts par l'auctoritas Ecclesiae et [ $\left.3^{\circ}\right]$ accomplis en toute bonne foi, c'est-à-dire veraciter et non mendaciter. Étant donné que $\left[4^{\circ}\right]$ ces gestes ou paroles ne peuvent être posés ou prononcés fictivement (non inaniter), il convient alors de s'interroger sur [ $\left.5^{\circ}\right]$ leur logique implicite. Celle-ci renvoie, dans le cas de la prière de demande ou d'action de grâce, à l'insuffisance des forces propres de l'orant;' Vinel, 'L'argument liturgique,' 237-38.

76 Serm. 115.3: Videant nunc, audiant ista nescio qui impie garrientes, et de suis uiribus praesumentes audiant qui dicunt, Deus me hominem fecit, iustum ipse me facio. $O$ peior et detestabilior Pharisaeo! Pharisaeus ille superbe quidem iustum se dicebat, sed tamen inde ille Deo gratias agebat. Iustum se dicebat; sed tamen Deo gratias agebat. Gratias tibi, Deus, quia non sum sicut ceteri homines [Luk. 18:11]. Gratias tibi Deus [Luk. 18:11]: gratias Deo agit, quia non est sicut ceteri homines: et tamen tanquam superbus et inflatus reprehenditur; non quia Deo gratias agebat, sed quia uelut nihil sibi addi cupiebat. Gratias tibi, quia non sum sicut ceteri homines, iniusti [Luk. 18:11]. Ergo tu iustus; ergo nihil rogas; ergo iam plenus es; ergo non est tentatio uita humana super terram; ergo iam plenus es; ergo iam abundas; ergo iam non est quare dicas, dimitte nobis debita nostra [Matt. 6:12]. Quid est ergo qui impie oppugnat gratiam, si reprehenditur qui superbe agit gratias? [PL 38 c. 656/52-657/12]. 
beings can be just by their own strengths, then no (additional) help from God is necessary. If this were the case, then no other grace from God exists other than the grace with which he created human being with a free will. ${ }^{77}$

Matthew 6:12 is cited profusely in Augustine's anti-Pelagian treatises. ${ }^{78} \mathrm{We}$ will discuss two writings situated at the beginning of the Pelagian controversy as an example. In De peccatorum meritis et remissione et de baptismo paruulorum (411), the prayer for forgiveness of sins (Matt. 6:12) and not being lead into temptation (Matt. 6:13) serves to prove that concupiscentia continues in us after baptism. ${ }^{79}$ After all, the wounds of sin still have to be healed in us and we do not have the capacity to fight concupiscentia unaided ${ }^{80}$ Augustine lists a number of biblical examples in support of his thesis. Daniel confessed his sins (Dan. 9:20), not only those of his people but his own personal sins also, as is evident from Daniel 9:5 and 11:15. Augustine then confronts his opponent: 'And surely you are ,no wiser than Daniel" (Ezek. 28:3).' According to Augustine, the example of Daniel also refutes the argument that the apostles were already holy, perfect, and without sin. It likewise refutes the claim that they did not pray Matthew 6:12 for themselves, but for the imperfect who were still sinners. ${ }^{81}$ While he admits that there have been many holy men and women, he immediately adds that they were not without sin. Each of them could apply the words of Matthew 6:12 to themselves and mean what they say ${ }^{82}$ Some claim, he observes, that there are people - in the past, present and future capable of using their reason who live without sin. He adds that such a situation is indeed something one might hope for, that one can aspire to it here and now, that one can pray for it, but that none of this makes it a reality. After baptism, all of us still have to pray Matthew 6:12. Augustine concludes that according to 1 John 1:8, those who claim that saintly people need not pray Matthew 6:12, and indeed that no one needs to pray it, are deceiving themselves. ${ }^{83}$

Matthew 6:12 plays a prominent role in De natura et gratia (spring 415) in Augustine's argument against the alleged 'Pelagian' thesis of the possibility of

77 Serm. 348a.9: Docuit enim nos Dominus quomodo oremus, nisi forte in orationibus nostris carnalia et temporalia postulemus, sicut est petere ne tibi doleat caput, ne moriaris, ne efferas filium, ne damnum patiaris, ne ab aliquo oppressus mittaris in carcerem, et si qua similia hic temporalia et saecularia sunt. Haec illi nobis concedunt orare; illud quod docuit Dominus tollunt, non quia negari illud audent, sed quia talia disputant unde tollatur. Cum enim tibi dicit: sufficis tibi ad faciendam iustitiam; si uis, facis; nullo adiutorio Dei opus habes ad implenda quae iussit, quia gratia Dei non est nisi ista quae te fecit cum libera uoluntate. [ReAu 28 p. 58/125-33].

For an extensive discussion on Matthew 6:12 in Augustine's writings, see our book, A. Dupont, Gratia in Augustine's Sermones ad Populum during the Pelagian Controversy: Do Different Contexts Furnish Different Insights? (Brill's Series in Church History 59; Leiden: Brill, 2013), 364-402.

79 Pecc. mer. rem. bapt. 2.4.

80 Ibid.

81 Ibid., 2.13 .

82 Ibid., 2.25.

83 Ibid., 3.23. 
sinlessness. Pelagius confronts Augustine with a dilemma: either saints die with sin - and are thus damned - or they die without sin, and Augustine must admit that they are 'sinless' ${ }^{84}$ Augustine points out in response that Pelagius has forgotten the prayer of Matthew 6:12. ${ }^{85}$ Daily prayer for the forgiveness of sins implies that it is possible to die without sin, but not possible to live without $\sin .{ }^{86}$ Pelagius quotes Augustine's De libero arbitrio 3.18.50 (387/388) in which the younger Augustine wrote that $\sin$ can be avoided. Confronted with this quotation, the older Augustine recognises that what he wrote is possible but only under the strict condition that it happens with the help of grace. It is for this reason that believers pray Matthew 6:12 for the forgiveness of previous sins and Matthew 6:13 to be able to avoid future sins. If we were able to do this on our own, there would be no need to pray for it. ${ }^{87}$ The combined prayer of Matthew 6:12-13, in other words, is evidence of the sinful reality of humankind.

Anne-Marie La Bonnardière has observed that the combined use of Matthew 6:12 and 1 John 1:8 is only to be found in Augustine's rebuke of Donatists and Pelagians, against what Augustine considers to be their self-righteousness,

84 Nat. grat. 40.

85 Pelagius is reproached by Augustine for being too unilateral in considering prayer a merely human initiative. Just as Pelagius denies the need for grace, he is likewise negative with respect to the appeal to prayer. While Pelagius explicitly affirmed the necessity of the phrase in the Lord's Prayer 'and lead us not into temptation', debate already existed on how exactly he interpreted the phrase. A number of Pelagians were convinced that human beings could resist temptation fully on their own and that God would never bring human beings into moral temptation. Incidentally, according to them, it is wrong to pray for something that God had already placed within the human capacity (of sinlessness) from the very beginning. This is why they claimed that the prayer 'and lead us not into temptation' signifies a request not to be put in physical danger (such as to fall from a horse or to be robbed). Cf. J. Comeliau, 'A propos de la prière de Pélage,' Revue d'Histoire Ecclésiastique 31 (1935): 77-89. J. Ferguson, Pelagius: A Historical and Theological Study (Cambridge: Heffer, 1956), 66, 94, 181-82. T.J. van Bavel, The Longing of the Heart: Augustine's Doctrine on Prayer (Leuven: Peeters, 2009). For the meaning and role of prayer in the totality of Pelagius's writings and his time, see: C. Garcia-Sanchez, Pelagius and Christian Initiation: A Study in Historical Theology (Washington D.C.: Catholic University of America Press, 1978), 274-84. It would appear from this study that while Pelagius did indeed write a number of times on prayer, it remained limited. Pelagius clearly did not ignore prayer, but it was evidently not central to his discourse. Such reproaches and such an interpretation do Pelagius an injustice, especially when we explore his treatment of prayer in his Comm. Rom. and other early writings.

86 Nat. grat. 41 [CSEL 60 p. 263/10-14].

87 Ibid., 80.

Nat. grat. 69: If it is (theoretically) possible to be without sin, then this is only possible thanks to the grace of God. According to Augustine, Pelagius has forgotten this.

Nat. grat. 70: According to Augustine, Pelagius does not want believers to pray for help in avoiding sin. Indeed, Pelagius even refuses to accept that human nature is wounded to such a degree that it cannot heal itself and is always in need of help. Augustine has serious doubts as to whether Psalm 142(143):2 (non iustificabitur in conspectu tuo omnis uiuens) can mean that people can be found in the present and the past who are completely righteous. In any event, the majority of people must pray Matthew 6:12 and the said majority is thus sinful. In the remainder of his treatise he argues that sinlessness is impossible in this world. 
respectively of a 'spotless church' and the possibility of sinlessness. She concludes that in Augustine's eyes: 'the Pelagians, with their interpretation of the Lord's Prayer, embarked on a journey of falsity. From his catechesis, Augustine very easily drew the lucid distinction of the triple veracity which has to be that of Christians: objective veracity: recognising the sinful condition of man; subjective veracity: not saying the Lord's Prayer unless one believes that one is a sinner, and existential veracity: really forgiving by mouth and by heart. With these three conditions met, one can recite the Lord's Prayer until the end, in all safety every day, in full Christian assembly and united with one's brothers. ${ }^{88}$ Thus we see how Matthew 6:12 for Augustine functioned as a criterion for orthodoxy, to unravel what he considers as the most problematic aspect of 'Pelagianism', their denial of human sin and divine grace. ${ }^{89}$

\subsection{An Exercise in Mystagogy: Reflections on Augustine's Exegesis of John 17}

In Matthew 6:12, Christ is depicted as teaching his followers to pray. Any time that Christ is directly quoted in the gospels serves to show words and deeds of special importance. How much more so is this the case when Christ himself not only teaches one to pray, but is depicted as praying. Indeed, Augustine sees a mystagogical moment in the High-Priestly Prayer, in which sapientia itself - mirabile dictum uttered a prayer. As he did in his transfiguration, Christ offers a vision of something of his glory. Through his prayer to his Father, Augustine avers, Christ is teaching his followers present there, as well as all who would hear or read this account in succeeding generations..$^{90}$ Christ teaches by both words and deeds; in fact, the latter are 'words' of a certain sort. ${ }^{91}$ All of Christ's deeds for Augustine teach us something. As Frederic Arsenault claims, 'The entire life of Christ is a message;' ${ }^{2}$ though again

88 '.... les Pélagiens, avec leur interprétation de l'oraison dominicale, s'engageaient en une voie de fausseté. Saint Augustin tira très simplement de sa catéchèse la distinction lucide de la triple véracité qui doit être celle des chrétiens: véracité objective: reconnaître la condition pécheresse de l'homme; véracité subjective: ne dire le Pater que si l'on se croit pécheur; véracité existentielle: pardonner réellement de bouche et de cœur. Ces trois conditions réunies, on peut en sécurité chaque jour, en pleine assemblée chrétienne et uni à ses frères, réciter jusqu'au bout l'Oraison dominicale;' A.-M. La Bonnardière, Les commentaires simultanés de Mat.6,12 et I Jo.I,8 dans l'oeuvre de s. Augustin,' Revue des Études Augustiniennes 1 (1955): 142-43.

89 'The Lord's Prayer again is the clearest testimony of the need for God's grace, Augustine says specifically in regards to the Sixth Petition. [n. 39: Epistula 177, 4.] If it were possible for people not to be tempted based upon their own abilities or spiritual powers, continues Augustine in this line of argument, then that petition would be silly and pointless. Even the fact that prayer is an expression of desire and a conforming of the will to God's will, says Augustine in a sermon on the Lord's Prayer, is a result of God's gracious work. [n. 40: Sermo 56, 4.];' Maschke, 'St. Augustine's Theology of Prayer,' 437.

$90 \quad$ Io. eu. tr. 104.2.

91 Marie Comeau, Saint Augustin: Exégète du quatrième Évangile (Paris: Beauchesne, 1930), 323.

92 Arsenault, Augustin, 36: 'Toute la vie du Christ est un message'. 
Augustine qualifies this view with a characteristic apophatic reflex. According to Rowan Williams, Augustine holds that '[i]t is [only] in heaven that we shall read the text that is God without obscurity - a text that is simultaneously the ordered creation, Scripture, and the radical love of the Word, the Son (see Conf. 13.15.18). ${ }^{93}$

But if Christ's life is properly called a 'word,' then it is most perfectly called a prayer. As God incarnate, Christ was always in perfect communion with his heavenly Father, of which one catches a fleeting glimpse in John $17 .{ }^{94}$ In his exegesis of this passage, Augustine suggests that the very essence of the Godhead is pellucidly if ephemerally displayed in Christ's words. That is, the reciprocal communication of love and praise between the Father and the Son, the very dynamic of which just is constitutive of the Holy Spirit, is shown in this prayer. As Christ prays, Augustine proclaims, he is teaching us and showing us something of the divine reality of which he himself is the manifestation par excellence, revealing the Trinitarian love at the basis of all creation..$^{95}$

Furthermore, in addition to revealing God, Christ also shows what it means to be truly human. Hence the discussion of prayer can again be cast in a new light. Augustine's treatment of prayer implies that to be human does not simply mean to pray, but to live in such a way that one's life becomes an oratio. This idea accords with Augustine's anthropology, which entails that to be a subject means essentially to be in communication, and indeed, in communion, with God. ${ }^{96}$ One upshot of this, from a philosophical perspective, is a remarkable break with the past, whether Hellenic or Hebraic, and the formulation of a novel anthropology which is at the same time inherently theological. ${ }^{97}$ To be human therefore is to communicate with, that is, to pray to, God. Moreover, the theological implication is that for Augustine, one is most wise, sapiens, and indeed, most human, homo, when one lives prayer, when one's very being becomes by degrees an act of recta religio, true worship.

\section{GENERAL CONCLUSION}

In his recent work on apophaticism in Augustine's theology, Van Geest has suggested that Augustine may be as much a mystagogue as a theologian, if not more so. If this is the case, then one would expect to see prayer as an integral if implicit aspect of his overall theological doctrine, a point which we have here laboured to establish. From the foregoing study, we have derived several lessons, and we have begun to see why prayer is so important for Augustine. One must pray in order to: 1) grow in sapientia, which is Christ; 2) attain eternal life, which is the completion of philosophy; 3 ) be

93 Williams, 'Augustine and the Psalms,' 26.

94 See D. V. Meconi, 'The Incarnation and the Role of Participation in St. Augustine's Confessions,' Augustinian Studies 29.2 (1998): 61-75.

95 Io. eu. tr. 105.3.

96 Bochet, 'Interprétation scriptuaire,' 40; cf. Trottmann, 'La Trinité.'

97 Bochet, 'Interprétation scriptuaire,' 39. 
truly human (imago Dei); and, 4) imitate Christ, who himself prayed, and so taught us to do likewise - in orthopraxis and orthodoxy - and graciously enables us to pray and works in us through that prayer.

We began with Augustine's understanding of sapientia, which, whilst heavily influenced by his classical philosophical background, ultimately came to acquire a theological, Christological, and even mystagogical character. Augustine's identification of sapientia with Christ implied that knowledge could not be attained merely by human efforts, or by the intellect alone. Rather, one could only ultimately arrive at Christ through prayer and true worship, the fullness of which was made available by Christ through his body, the church. By being initiated into the divine mysteries and incorporated into Christ's body, one could set a course for the eschaton by sailing upon the wood of the cross. In particular, as we have seen, whilst human limitations were such that the very goal of human existence eluded the grasp of the efforts of mere mortals, one could open oneself to transformation through the church's treasury, in particular her Scriptures, her sacraments, and above all, her divine liturgy: praestet fides supplementum sensuum defectui. As is the case with all patristic theology, Augustine's thinking is biblically inspired and oriented. In this regard, we saw that the Bible, especially as read, sung, and prayed during the liturgy of the church, is the main mystagogical source for Augustine. In particular, we explored Augustine's reflections about two Christological-biblical prayers: Matthew 6:12 and John 17.

The prayer of Matthew 6:12 features frequently in Augustine's thinking and writing. In particular, it contains three major points: the necessity to forgive, the reality of human sin, and the operation of grace. Most often, it serves as an exhortation to forgive others rooted in our covenant with God. Pointing to our ongoing infirmitas, it serves to encourage forgiveness and figures as a remedy against daily sin. Augustine accuses Manicheans, Donatists, and Pelagians of being hypocritical in praying Matthew 6:12. All three movements in their own way did not believe in the content of Matthew 6:12 and were thus being duplicitous when they prayed it. Augustine observes that the Manicheans, Donatists, and Pelagians pray the words of Matthew 6:12 and invites them to be consistent and to believe in its content. The text refutes Manichean dualism. Within the framework of the anti-Donatist polemic, he employs the verse in the first instance to insist that none of us is completely free of sin, including ministers of the sacraments. The verse is explicitly present within the Pelagian controversy as an argument against the impeccantia hypothesis. According to Augustine, the prayer for forgiveness in Matthew 6:12 testifies to a basic spiritual attitude, namely the humble recognition of one's own weakness. The daily prayer of Matthew 6:12 proves that no one is without sin after baptism, and in constant need of grace. That this prayer in itself also is grace is not often formulated in an explicit way by Augustine. He concentrates rather on the rationale behind prayer, namely sin. 
Yet what rationale could lie behind the prayer offered by the sinless Son of God in the midst of his disciples? Drawing upon Augustine's theology of 'reading' facts and actions, such as those of Christ, like a text, and in connection with other facets of his thinking, we have attempted to tease out the implications of his treatment of John 17. Hazarding a mystagogical step of our own, we have argued that Augustine's exegesis of the High-Priestly Prayer, of which we have only scratched the surface, implies that among other things, Christ is revealing the very nature of the Trinitarian life as God's self-communication sourced by caritas, as well as pointing to that in which the fulfilment of human nature consists, namely communion with God, or to call a rose by another name, prayer.

On a final note, we might reflect here on certain ways forward suggested by our research. At the outset, we identified certain motivations for our paper arising from apparent lacunae in recent scholarship, in particular concerning Augustine's understanding of prayer and sapientia. We can say with some confidence that our re-evaluation at these topics has been helpful and warrants to be continued. But in closing, perhaps we could intimate yet another way forward, one which goes to the heart of philosophy and theology today. Scholars such as Van Geest have suggested that Augustine's emphasis on mystagogy entails an approach to truth which goes beyond univocal, Euclidean forms of rationality. ${ }^{98}$ In light of these ideas, our contention is that a reconsideration of Augustinian epistemic themes, even those connected with prayer, could provide helpful resources for overcoming some contemporary conundrums generated by 'geometrical' accounts of human reason. Augustine's compelling and indeed radically different way of conceiving of wisdom and knowledge promises to yield fruitful challenges within our own intellectual contexts, and could prove interesting for overcoming the modern anti-thesis posited between the heart and the head.

\section{BIBLIOGRAPHY}

Arsenault, F. Augustin: Qui est Jésus Christ? Paris: Desclée, 1974.

Augustine, Answer to the Pelagians, I/23. Edited by J.E. Rotelle. Translated by R. Teske. The Works of Saint Augustine: A Translation for the 21st Century I/23. Hyde Park, NY: New City, 1997.

Beatrice, P.F. 'Lord's Prayer.' M. O'Connell, trans. Pages 506-9 in Augustine through the Ages. Edited by A.D. Fitzgerald. Grand Rapids, MI: Eerdmans, 1999.

Bochet, Isabelle. 'Herméneutique, apologétique et philosophie. Recherches sur Augustin. Exposé de soutenance en vue de l'obtention d'une these d'Habilitation à Diriger des Recherches,

98 Van Geest, The Incomprehensibility of God, 66. See also: Lydia Schumacher, Divine Illumination: The History and Future of Augustine's Theory of Knowledge (Malden, MA: Wiley-Blackwell, 2011). 
Paris IV-Sorbonne, 11 octobre 2002.' Revue des Études Augustiniennes et Patristiques 48 (2002): 321-9.

—. 'Interprétation scripturaire et compréhension de soi: Du De Doctrina Christiana aux Confessions de Saint Augustin.' Pages 21-50 in Comprendre et interpréter: Le paradigme herméneutique de la raison. Edited by J. Greisch. Paris: Beauchesne, 1993.

__. ',Non aliam esse philosophiam (...) et aliam religionem“ (Augustin, De uer. rel. 5, 8).' Pages 333-53 in Les Apologistes chrétiens et la culture grecque. Edited by B. Pouderon and J. Doré. Théologie Historique 105. Paris: Beauchesne, 1998.

Burton, P. 'The Vocabulary of the Liberal Arts in Augustine's Confessions.' Pages 141-64 in Augustine and the Disciplines. Edited by K. Pollmann and M. Vessey. Oxford: Oxford University Press, 2005.

Cassidy, E. 'Augustine's Exegesis of the First Epistle of John.' Pages 201-20 in Scriptural Interpretation in the Fathers: Letter and Spirit. Edited by T. Finan and V. Twomey. Dublin: Four Courts, 1995.

Comeau, Marie. Saint Augustin: Exégète du quatrième Évangile. Paris: Beauchesne, 1930.

Comeliau, J. 'À propos de la prière de Pélage.' Revue d'Histoire Ecclésiastique 31 (1935): 77-89.

Dodaro, R. '„Omnes haeretici negant Christum in carne uenisse“(Aug., serm. 183.9.13): Augustine on the Incarnation as Criterion for Orthodoxy.' Augustinian Studies 38, 1 (2007): 163-74.

Doignon, Jean. 'La prière liminaire des Soliloquia, dans la ligne philosophique des dialogues des Cassiciacum.' Pages 85-105 In Augustiniana Traiectina. Communications au Colloque International d'Utrecht 1986. Edited by J. den Boeft and J. van Oort. Paris: Études Augustiniennes, 1987.

Doucet, Dominique. 'Recherche de Dieu, Incarnation et philosophie: Sol. I, 1, 2-6.' Revue des Études Augustiniennes et Patristiques 36 (1990): 91-119.

Drever, Matthew. 'The Self Before God? Rethinking Augustine's Trinitarian Thought.' Harvard Theological Review 100, 2 (2007): 233-42.

Dupont, Anthony. Gratia in Augustine's Sermones ad Populum during the Pelagian Controversy: Do Different Contexts Furnish Different Insights? Brill's Series in Church History 59. Leiden: Brill, 2013.

Ferguson, J. Pelagius: A Historical and Theological Study. Cambridge: Heffer, 1956.

Finan, Thomas. 'St Augustine on the „mira profunditas” of Scripture: Texts and Contexts.' Pages 163-99 in Scriptural Interpretation in the Fathers: Letter and Spirit. Edited by T. Finan and V. Twomey. Dublin: Four Courts, 1995.

Garcia-Sanchez, C. Pelagius and Christian Initiation: A Study in Historical Theology. Washington D.C.: Catholic University of America Press, 1978.

Holte, Ragnar. Béatitude et sagesse: St Augustin et le problème de la fin de l'homme. Paris: Études Augustiniennes, 1962.

Kuehn, E.F. 'The Johannine Logic of Augustine's Trinity: A Dogmatic Sketch.' Theological Studies 68 (2007): 572-94.

La Bonnardière, A.-M. 'Les commentaires simultanés de Mat.6,12 et I Jo.I,8 dans l'oeuvre de s. Augustin.' Revue des Études Augustiniennes 1 (1955): 142-43. 
Lössl, Josef. 'The One (unum) - A Guiding Concept in De uera religione: An Outline of the Text and the History of Its Interpretation.' Revue des Études Augustiniennes 40 (1994): 79-103.

Madec, Goulven. 'Christus, scientia et sapientia nostra: Le principe de cohérence de la doctrine augustinienne.' Recherches Augustiniennes 10 (1976): 77-85.

—. 'Une lecture de Confessions VII.' Recherches Augustiniennes 10 (1975): 79-137.

Maschke, Th. 'St. Augustine's Theology of Prayer: Gracious Conformation.' Pages 431-46 in Augustine. Presbyter Factus Sum. Edited by J.T.E. Lienhard, C. Muller, and R.J. Teske. Collectanea Augustiniana. New York: Peter Lang, 1993.

Mayer, C., ed. Augustinus-Lexikon. Vol. II. Basel: Schwabe, 2001.

Mechlinsky, L. Der 'modus proferendi' in Augustins 'sermones ad populum'. Studien zur Geschichte und Kultur des Altertums. Neue Folge 23. Paderborn: Schöningh, 2004.

Meconi, David V. 'Becoming Gods by Becoming God's: Augustine's Mystagogy of Identification.' Augustinian Studies 39, 1 (2008): 61-74.

- 'The Incarnation and the Role of Participation in St. Augustine's Confessions.' Augustinian Studies 29, 2 (1998): 61-75.

Pardue, S. 'Kenosis and its Discontents: Towards an Augustinian Account of Divine Humility.' Scottish Journal of Theology 65.3 (2012): 271-88.

Pollmann, Karla. 'Augustine's Hermeneutics as a Universal Discipline!?' Pages 206-31 in Augustine and the Disciplines. Edited by K. Pollmann and M. Vessey. Oxford: Oxford University Press, 2005.

Poque, S. 'Le Christ „,iurisperitus“ et la procédure „per rescriptum“ dans la prédication d'Augustin d'Hippo.' Revue Historique de Droit Français et Étranger 57 (1979): 331-44.

Rebillard, É. In hora mortis: Évolution de la pastorale chrétienne de la mort aux IVe et Ve siècles. Bibliothèque des Écoles Françaises d'Athènes et de Rome 283. Rome: École Française de Rome, 1994.

Schumacher, Lydia. Divine Illumination: The History and Future of Augustine's Theory of Knowledge. Malden, MA: Wiley-Blackwell, 2011.

Trottmann, Christian. 'La Trinité de la Sagesse: Contemplation philosophique et guérison mystique.' Questio 6 (2006): [xy].

Van Bavel, T.-J. The Longing of the Heart: Augustine's Doctrine on Prayer. Leuven: Peeters, 2009.

Van Geest, Paul. The Incomprehensibility of God: Augustine as a Negative Theologian. Late Antique History and Religion 4. Leuven: Peeters, 2011.

Van Riel, Gerd. 'La sagesse chez Augustin: De la philosophie à l'Écriture.' Pages 389-405 in Augustin philosophe et prédicateur: Hommage a Goulven Madec (Collection des Études Augustiniennes, Série Antiquité 195. Edited by Isabelle Bochet. Paris: Institut d'Études Augustiniennes, 2012.

Vannier, M.-A. 'Creatio,' ‘conversio, ' ‘formatio' chez S. Augustin. Paradosis 31. Fribourg: Éditions universitaires, 1991.

Vinel, J.-A. 'L'argument liturgique opposé par saint Augustin aux Pélagiens.' Questions liturgiques 68 (1987): 209-41. 
Weaver, R.H. 'Prayer.' Pages 672-3 in Augustine through the Ages. Edited by A.D. Fitzgerald; Grand Rapids, MI: Eerdmans, 1999.

Williams, Rowan. 'Augustine and the Psalms.' Interpretation 58, 1 (2004): 17-27. 